\title{
Natural Antioxidants from Endemic Leaves in the Elaboration of Processed Meat Products: Current Status
}

\author{
Lidiana Velázquez $^{1}$, John Quiñones ${ }^{1,2} \mathbb{D}$, Rommy Díaz ${ }^{3}$, Mirian Pateiro ${ }^{4}\left(\mathbb{D}\right.$, José Manuel Lorenzo ${ }^{4,5} *^{\mathbb{D}}$ \\ and Néstor Sepúlveda $1,6, * \mathbb{D}$
}

1 Centro de Tecnología e Innovación de la Carne (CTI-Carne), Programa de Doctorado en Ciencias Agroalimentarias y Medioambiente, Universidad de La Frontera, Temuco 4780000, Chile; 1.velazquez01@ufromail.cl (L.V.); john.quinones@ufrontera.cl (J.Q.)

2 Departamento de Ingeniería Química, Facultad de Ingeniería y Ciencias, Universidad de La Frontera, Temuco 4780000, Chile

3 Departamento de Ciencias Básicas, Facultad de Medicina, Universidad de La Frontera, Temuco 4780000, Chile; rommy.diaz@ufrontera.cl

4 Centro Tecnológico de la Carne de Galicia, Avd. Galicia No. 4, Parque Tecnológico de Galicia, San Cibrao das Viñas, 32900 Ourense, Spain; mirianpateiro@ceteca.net

5 Área de Tecnología de los Alimentos, Facultad de Ciencias de Ourense, Universidad de Vigo, 32004 Ourense, Spain

6 Departamento de Producción Agropecuaria, Facultad de Ciencias Agropecuarias y Forestales, Universidad de La Frontera, Temuco 4780000, Chile

* Correspondence: jmlorenzo@ceteca.net (J.M.L.); nestor.sepulveda@ufrontera.cl (N.S.)

Citation: Velázquez, L.; Quiñones, J.; Díaz, R.; Pateiro, M.; Lorenzo, J.M.; Sepúlveda, N. Natural Antioxidants from Endemic Leaves in the Elaboration of Processed Meat Products: Current Status. Antioxidants 2021, 10, 1396. https:// doi.org/10.3390/antiox10091396

Academic Editor: Per Ertbjerg

Received: 3 July 2021

Accepted: 7 August 2021

Published: 31 August 2021

Publisher's Note: MDPI stays neutral with regard to jurisdictional claims in published maps and institutional affiliations.

Copyright: () 2021 by the authors. Licensee MDPI, Basel, Switzerland. This article is an open access article distributed under the terms and conditions of the Creative Commons Attribution (CC BY) license (https:// creativecommons.org/licenses/by/ $4.0 /)$.
Abstract: During the last few years, consumers' demand for animal protein and healthier meat products has increased considerably. This has motivated researchers of the meat industry to create products that present healthier components while maintaining their safety, sensory characteristics, and shelf life. Concerning this, natural plant extracts have gained prominence because they can act as antioxidants and antimicrobials, increasing the stability and shelf life of processed meat products. It has been observed that the leaves of plant species (Moringa oleifera, Bidens pilosa, Eugenia uniflora, Olea europea, Prunus cerasus, Ribes nigrum, etc.) have a higher concentration and variety of polyphenols than other parts of the plants, such as fruits and stems. In Chile, there are two native berries, maqui (Aristotelia chilensis) and murtilla (Ugni molinae Turcz), that that stand out for their high concentrations of polyphenols. Recently, their polyphenols have been characterized, demonstrating their potential antioxidant and antimicrobial action and their bioactive action at cellular level. However, to date, there is little information on their use in the elaboration of meat products. Therefore, the objective of this review is to compile the most current data on the use of polyphenols from leaves of native plants in the elaboration of meat products and their effect on the oxidation, stability, and organoleptic characteristics during the shelf life of these products.

Keywords: meat; charcuterie; native species; natural preservatives; polyphenols; shelf life

\section{Introduction}

Processed meat products are highly perishable foods that undergo a series of chemical reactions that, notably, significantly decrease their shelf life [1]. Lipid oxidation is recognized as the main agent responsible for the degradation of meat and processed meat products [2]. However, these biochemical processes together with proteolysis are essential for the synthesis of aromatic compounds (alkanes, aldehydes, alcohols, esters, and carboxylic acid) characteristic of matured meat products [3,4]. One of the most widely used barrier technologies to improve the stability of meat and meat products is the use of synthetic additives, such as butylated hydroxytoluene (BHT), butylated hydroxyanisole (BHA), tertiary butylhydroquinone (TBQH), and propyl gallate (GP), which limit the oxidation and inhibit the microbial growth [5]. Still, some of these compounds, such as BHT, are 
volatile at high temperatures, and their regular consumption increases the risk of cancer. For this reason, consumers are becoming more conscious and want to be informed about what they buy, avoiding foods with artificial additives while increasing their preferences for functional foods (with clean labels) made from natural, raw materials [6,7].

To cover the demands of new consumers, researchers in the meat industry are focused on creating new formulations with more organic and healthier components $[8,9]$. In this sense, natural plant extracts are an excellent alternative because of their health benefits and their ability to extend the shelf life of foods [10-12]. Foods of plant origin contain compounds, such as flavonoids, vitamins, tannins, organic acids, alkaloids, and phenolic acids, that are effective against oxidative processes and microbial growth in meat [13]. In addition, in some cases, they can act as emulsifiers or provide new sensory characteristics to these products. In this regard, the extracts from the leaves of a wide variety of plants (Azadirachta indica, Bidens pilosa, Camellia sinensis, Coriandrum sativum, Eugenia uniflora, Hippophae rhamnoides, Ilex paraguariensis, Juglans regia, Moringa oleifera, Olea europea, Origanum vulgare, Prunus cerasus, Ribes nigrum, Salvia leriifolia, Salvia Rosmarinus, Satureja hortensis, Urtica dioica, Vaccinium myrtillus, among others) have been studied for their in the elaboration of meat formulations, such as frankfurters, ground meat, hamburgers, meatballs, sausages, etc. [14-18].

Recently, the high presence of bioactive compounds in berry fruits has been noted as well as their health benefits, which have been demonstrated through experimental, clinical, and epidemiological evidence $[19,20]$. Southern Latin America and especially southern Chile is a reservoir of a diversity of native berry species that constitute a potential source of natural compounds for the elaboration of functional meat products. Among these native berries, Aristotelia chilensis and Ugni molinae Turcz are particularly interesting for their high levels of bioactive compounds. The berries of these plants are consumed as fruits and are also used for the artisanal and industrial elaboration of marmalade, preserves, ice cream, and juice concentrates but also in the pharmaceutical industry as raw material for the elaboration of food supplements [21,22]. Moreover, the international demand for these superfoods has increased considerably, and they are now exported to several countries in Europe, the United States, South Korea, Japan, Australia, and Denmark, among others [23]. This has also increased the by-products generated during the harvesting of these fruits, among which are their leaves. These are not used despite their phytochemical richness, which could make a significant contribution to the production of healthier meat products [20]. On the other hand, there are hardly any studies that include leaf extracts of Aristotelia chilensis and Ugni molinae for the preservation of processed meat products. Therefore, this review aims to provide a description of the polyphenols present in the leaves of Aristotelia chilensis and Ugni molinae as well as their in-vitro antioxidant and antimicrobial activity. Furthermore, it compiles the most current data on the use of the other native plants (mentioned above) as potential natural antioxidant and antimicrobial alternatives to synthetic additives in the meat industry, evaluating their effect on the oxidation, stability, and organoleptic characteristics during the shelf life of these products.

\section{Leaves of Endemic Plants as Ingredients in Processed Meat Products}

The natural antioxidants commonly used in the preparation of meat products are extracted from different parts of plants [10,24]. Both the composition and the concentration of these extracts can vary depending on where they have been obtained (fruits, peels, seeds, stems, or leaves). Many studies have characterised, quantified, and compared the polyphenols from different parts of plants. They agree that leaves generally have a greater variety and concentration of these bioactive compounds as well as a higher antioxidant capacity $[25,26]$. In this regard, extracts from the leaves of a wide variety of fruits, vegetables, and spices have been tested in the form of aqueous and hydroalcoholic extracts or as powders in meat products, such as meatballs, burgers, sausages, and ground meat $[8,17,27]$. In general, the inclusion of these extracts favours the stability of meat products by prolonging their shelf life (Table 1). Nevertheless, it is very important to evaluate both the composition and the dosage 
of these extracts in new formulations since, in addition to polyphenols, the leaves can also contain other bioactive compounds (vitamins and nitrogenous species-alkaloids, chlorophyll derivatives, amino acids, and amines) that could affect quality indicators as flavour or act as pro-oxidants $[28,29]$. This would be the case of alkaloids, which can give meat products a bitter flavour [30]. In this sense, it has been observed that when using concentrations between 200-1000 ppm, a good antioxidant and antimicrobial effect is achieved, enhancing, in some cases, the organoleptic characteristics $[17,31]$.

Table 1. Effect of natural extracts obtained from the leaves of different endemic plants on the shelf life of processed meat products.

\begin{tabular}{|c|c|c|c|c|c|}
\hline Plant Leaves & $\begin{array}{c}\text { Meat } \\
\text { Product }\end{array}$ & Extract Dose & $\begin{array}{c}\text { Storage } \\
\text { Conditions }\end{array}$ & Main Results & Ref. \\
\hline $\begin{array}{l}\text { Black and green tea } \\
\text { (Camellia sinensis L.) }\end{array}$ & $\begin{array}{l}\text { Uncured pork } \\
\text { frankfurters }\end{array}$ & $\begin{array}{l}0.05,0.10,0.20 \\
\text { and } 0.30 \%\end{array}$ & $\begin{array}{l}5 \text { days } \\
\text { at } 37^{\circ} \mathrm{C}\end{array}$ & $\begin{array}{l}\text { Phenolic extracts inhibited the } \\
\text { formation of hydroperoxides. } \\
\text { Polyphenol extracts did not affect } \\
\text { colour, odour, texture, juiciness, } \\
\text { flavour, or general acceptability. }\end{array}$ & [15] \\
\hline $\begin{array}{c}\text { Black currant } \\
\text { (Ribes nigrum L.), } \\
\text { Cherry (Prunus cerasus L.) }\end{array}$ & $\begin{array}{l}\text { Pork } \\
\text { frankfurters }\end{array}$ & $\begin{array}{l}\text { BCS } 1.0 \mathrm{~g} / 100 \mathrm{~g} \\
\text { CHS } 0.5 \mathrm{~g} / 100 \mathrm{~g}\end{array}$ & $\begin{array}{l}28 \text { days } \\
\text { at } 4{ }^{\circ} \mathrm{C}\end{array}$ & $\begin{array}{c}\text { Samples treated with natural } \\
\text { extracts showed significantly lower } \\
\text { counts of Brochothrix thermosphacta, } \\
\text { LAB, mesophiles, and } \\
\text { psychrotrophs. Polyphenols from } \\
\text { leaves of } P \text {. cerasus and } R \text {. nigrum } \\
\text { inhibited MDA formation by } 15.29 \% \\
\text { and } 21.48 \% \text {, respectively. }\end{array}$ & [17] \\
\hline $\begin{array}{l}\text { Black currant (Ribes nigrum L.), } \\
\text { Blueberry (Vaccinium myrtillus } \\
\text { L.), Garden savory (Satureja } \\
\text { hortensis L.), Sea buckthorn } \\
\text { (Hippophae rhamnoides L.) }\end{array}$ & $\begin{array}{l}\text { Cooked } \\
\text { meatballs }\end{array}$ & 100 and 200 ppm & $\begin{array}{l}14 \text { days } \\
\text { at } 4{ }^{\circ} \mathrm{C}\end{array}$ & $\begin{array}{l}\text { Aqueous extracts inhibited lipid } \\
\text { oxidation by } 13.8-21.8 \% \text { during } \\
14 \text { days of cold storage. }\end{array}$ & [18] \\
\hline $\begin{array}{c}\text { Cadillo (Bidens pilosa), } \\
\text { Moringa oleifera }\end{array}$ & Ground beef & 0.5 and $1 \mathrm{~g} / \mathrm{kg}$ & $\begin{array}{l}6 \text { days } \\
\text { at } 4{ }^{\circ} \mathrm{C}\end{array}$ & $\begin{array}{l}\text { The extracts obtained from the } \\
\text { leaves of } M \text {. oleifera and B. pilosa } \\
\text { showed a polyphenol content of } \\
77.5 \text { and } 75.9 \text { mg GAE/g dw, } \\
\text { respectively. Both plants displayed } \\
\text { inhibitory effects ( } 1 \mathrm{~g} / \mathrm{kg} \text { ) against } \\
\text { Staphylococcus aureus, Bacillus cereus, } \\
\text { Enterococcus faecalis, and Escherichia } \\
\text { coli, although the higher activity } \\
\text { was observed against } \\
\text { gram-negative bacteria. }\end{array}$ & [32] \\
\hline $\begin{array}{c}\text { Cilantro } \\
\text { (Coriandrum sativum) }\end{array}$ & $\begin{array}{l}\text { Turkey } \\
\text { meatballs }\end{array}$ & 200 and 500 ppm & $\begin{array}{l}9 \text { days } \\
\text { at } 4{ }^{\circ} \mathrm{C}\end{array}$ & $\begin{array}{l}\text { The addition of } C \text {. sativum extract at } \\
500 \mathrm{ppm} \text { delayed lipid oxidation by } \\
58.33 \% \text { during } 6 \text { days of storage and } \\
\text { inhibited the growth of aerobic } \\
\text { microorganisms for } 9 \text { days } \\
\text { of storage. }\end{array}$ & [27] \\
\hline $\begin{array}{l}\text { Green tea } \\
\text { (Camellia sinensis L.), } \\
\text { Nettle (Urtica dioica L.), } \\
\text { Olive (Olea europea L.) }\end{array}$ & $\begin{array}{l}\text { Frankfurter } \\
\text { sausages }\end{array}$ & 500 ppm & $\begin{array}{l}45 \text { days } \\
\text { at } 4{ }^{\circ} \mathrm{C}\end{array}$ & $\begin{array}{l}\text { The ethanolic extracts of } C \text {. sinensis, } \\
\text { U. dioica, and O. europea leaves } \\
\text { inhibited lipid oxidation by } 40 \% \text {, } \\
20 \% \text {, and } 26 \% \text {, respectively. }\end{array}$ & [14] \\
\hline $\begin{array}{l}\text { Indian nimbus } \\
\text { (Azadirachta indica) }\end{array}$ & $\begin{array}{l}\text { Raw, chilled beef } \\
\text { patties }\end{array}$ & $0.7 \%(w / w)$ & $\begin{array}{l}5 \text { days } \\
\text { at } 4{ }^{\circ} \mathrm{C}\end{array}$ & $\begin{array}{l}\text { The hydroalcoholic extract limited } \\
\text { colour loss and reduced } \\
\text { metmyoglobin formation ( } 36.70 \%) \text {. } \\
\text { It prevented MDA formation by } \\
67.30 \% \text { after } 11 \text { days of storage, } \\
\text { which was similar to the values } \\
\text { found with the synthetic } \\
\text { antioxidant ( } 66.34 \%) \text {. Antimicrobial } \\
\text { activity was observed against most } \\
\text { of the bacterial strains tested, with } \\
\text { the best observed activity against } \\
\text { E. coli strains. }\end{array}$ & [8] \\
\hline
\end{tabular}


Table 1. Conts.

\begin{tabular}{|c|c|c|c|c|c|}
\hline Plant Leaves & $\begin{array}{c}\text { Meat } \\
\text { Product }\end{array}$ & Extract Dose & $\begin{array}{l}\text { Storage } \\
\text { Conditions }\end{array}$ & Main Results & Ref. \\
\hline $\begin{array}{c}\text { Mate } \\
\text { (Ilex paraguariensis) }\end{array}$ & $\begin{array}{l}\text { Fermented } \\
\text { Italian-type } \\
\text { sausages }\end{array}$ & $0.3-0.4 \%$ & $\begin{array}{l}60 \text { days } \\
\text { at } 18^{\circ} \mathrm{C}\end{array}$ & $\begin{array}{l}\text { Aqueous extracts added at } 0.4 \% \\
\text { reduced oxidation by } 32.87 \% \text { during } \\
60 \text { days of storage. Sensory } \\
\text { characteristics (flavour, texture, and } \\
\text { overall acceptability) were not } \\
\text { affected by the addition of } \\
\text { I. paraguariensis extract. }\end{array}$ & [33] \\
\hline $\begin{array}{c}\text { Oregano } \\
\text { (Origanum vulgare) }\end{array}$ & Marinated pork & $0.5-2 \%$ & $\begin{array}{l}10 \text { days } \\
\text { at } 4^{\circ} \mathrm{C}\end{array}$ & $\begin{array}{l}\text { Aqueous and ethanolic extracts of } \\
\text { O. vulgare added at } 2 \% \text { inhibited } \\
\text { lipid oxidation by } 63.2 \% \text { during } \\
10 \text { days of storage. The extracts } \\
\text { showed inhibitory power against } \\
\text { the growth of Enterobacteria } \\
\text { and Enterococci. }\end{array}$ & [34] \\
\hline $\begin{array}{c}\text { Pitanga } \\
\text { (Eugenia uniflora) }\end{array}$ & Pork burgers & $\begin{array}{c}\text { 250, } 500 \text { and } 1000 \\
\text { ppm }\end{array}$ & $\begin{array}{l}18 \text { days } \\
\text { at } 4^{\circ} \mathrm{C}\end{array}$ & $\begin{array}{l}\text { Hydroalcoholic extracts showed to } \\
\text { inhibit the growth of Salmonella spp., } \\
\text { Bacillus cereus, Staphylococcus aureus, } \\
\text { and Pseudomonas aeruginosa. }\end{array}$ & [29] \\
\hline \multirow[b]{2}{*}{$\begin{array}{c}\text { Rosemary } \\
\text { (Salvia Rosmarinus) }\end{array}$} & $\begin{array}{c}\text { Frozen pork, } \\
\text { turkey and } \\
\text { chicken patties }\end{array}$ & $0.03 \%$ and $0.06 \%$ & $\begin{array}{l}120 \text { days } \\
\text { at }-12{ }^{\circ} \mathrm{C}\end{array}$ & $\begin{array}{l}\text { The proximate composition of the } \\
\text { different formulations did not show } \\
\text { significant differences. The } \\
\text { concentration of natural } \\
\text { antioxidants was sufficient to } \\
\text { maintain the oxidative stability of } \\
\text { the products during frozen storage. }\end{array}$ & [16] \\
\hline & $\begin{array}{c}\text { Duck } \\
\text { meatballs }\end{array}$ & $1 \%$ & $\begin{array}{l}15 \text { days } \\
\text { at } 3^{\circ} \mathrm{C}\end{array}$ & $\begin{array}{l}\text { Meatballs with extracts of } \\
\text { S. rosmarinus inhibited } \\
\text { hydroperoxide formation by } 80.7 \% \text {. } \\
\text { The counts of psychrotrophic and } \\
\text { coliform bacteria were lower in } \\
\text { meatballs containing rosemary } \\
(\leq 10 \mathrm{cfu} / \mathrm{g}) \text { compared to those } \\
\text { found in control sample }\left(1.3 \times 10^{4}\right. \\
\text { and } 8.7 \times 10^{2} \mathrm{cfu} / \mathrm{g} \text {, respectively) }\end{array}$ & [35] \\
\hline $\begin{array}{c}\text { Salvia } \\
\text { (Salvia leriifolia) }\end{array}$ & Burgers & $\begin{array}{c}5,10,15 \text { and } 20 \\
\mathrm{mg} / \mathrm{L}\end{array}$ & $\begin{array}{l}45 \text { days } \\
\text { at }-12{ }^{\circ} \mathrm{C}\end{array}$ & $\begin{array}{l}\text { The inclusion of powdered leaves of } \\
\text { S. officinalis decreased the growth of } \\
\text { S. aureus and TVC. This effect was } \\
\text { significant at } 15 \text { and } 30 \text { days of } \\
\text { storage, respectively. }\end{array}$ & [36] \\
\hline $\begin{array}{c}\text { Walnut } \\
\text { (Juglans regia L.) }\end{array}$ & Pork meat & $\begin{array}{l}\text { Extract }(5.5 \%) \text { or } \\
\text { powder }(0.5 \%)\end{array}$ & $\begin{array}{l}15 \text { days } \\
\text { at } 4^{\circ} \mathrm{C}\end{array}$ & $\begin{array}{l}\text { Aqueous extracts reduced MDA } \\
\text { formation by } 47.5 \% \text { after } 15 \text { days of } \\
\text { storage compared to controls, } \\
\text { including samples without } \\
\text { antioxidants and samples } \\
\text { with } 0.1 \% \text { BHT. }\end{array}$ & [37] \\
\hline
\end{tabular}

BCS, blackcurrant leaf extract; CHS, sour cherry leaf extract; dw, dry weight; MDA, malonaldehyde; TVC, total viable counts.

On the other hand, the conditions under which the polyphenol extraction is performed must also be taken into account. It is known that the extraction conditions (particle size, extraction temperature, solid-solvent ratio, type of solvent, and extraction method) determine the yield and composition of the phytochemicals obtained and their antioxidant and antimicrobial capacities $[38,39]$. In this respect, it has been reported that some bioactive compounds, such as anthocyanins, phenolic glycosides, and flavonoids, are unstable at high temperatures, leading to their degradation and loss of function [40]. Likewise, the chemical and molecular properties of the solvent are critical factors since, with the appropriate solvent, the selectivity on the target molecules, and thus the extraction efficiency, is increased [26,41]. In particular, it has been observed that carotenoids, tocopherols, polymeric proanthocyanidins, and high-molecular-weight tannins are extracted in organic media due to their lipophilic character [42]. Moreover, some flavonols, such as catechin hydrate and 
ellagic acid, are best extracted when 50\% ethanol is used, while glycosidase flavonoids and gallic acid and its derivatives are more easily extracted with distilled $\mathrm{H}_{2} \mathrm{O}$ [25]. In addition, extraction methods should be evaluated, as some may increase the extraction efficiency compared to conventional methods [43].

\section{Effect of Natural Leaf Extracts on the Quality of Processed Meat Products}

\subsection{Physicochemical Parameters}

The incorporation of natural antioxidants into processed meat products in the form of extracts or powders prevents lipid oxidation and retards microbial growth, resulting in improved stability and longer shelf life $[16,26]$. However, these compounds can induce variations in other physicochemical, microbiological, and organoleptic parameters that are quality indicators of processed meat products. Among these is $\mathrm{pH}$, which functions as a selective barrier to microbial growth and influences the water holding capacity (WHC) of the processed meat products and, therefore, their texture. Changes in $\mathrm{pH}$ during storage can have multiple causes. For example, it has been reported that the decrease in $\mathrm{pH}$ can be a consequence of the presence of fatty acids and/or free amino acids in the medium, which are generated as a result of lipolysis or proteolysis that these foods may undergo. Additionally, a significant influence may be the accumulation of acidic secondary metabolites, such as lactic acid, which are formed during microbial growth $[42,44]$. On the other hand, high $\mathrm{pH}$ levels indicate the formation of basic substances, such as ammonia, which are also formed by microbial proteolysis [45]. Several studies demonstrate that there is a maximum $\mathrm{pH}$ limit established for meat products. In this regard, a study conducted by Ali et al. [46] showed that beef sausages that had been treated with oregano (Origanum vulgare) powder and other natural spices maintained a $\mathrm{pH}$ between 6.42-6.51 on the twelfth day of storage, while control sausages (without antioxidants) reached a $\mathrm{pH}$ of 6.98 on the sixth day of storage, leading to visible signs of deterioration. In addition, products with $\mathrm{pH}$ values higher than 7.4 are discarded due to their poor organoleptic characteristics [16]. Karpińska-Tymoszczyk [35] also observed an increase in pH after three days of storage in duck meatballs treated with rosemary (Salvia Rosmarinus) leaf extracts (1\%). Conversely, Falowo et al. [32] and Alirezalu et al. [14] perceived a significant decrease in $\mathrm{pH}$ in samples of veal meat treated with hydroalcoholic extracts of moringa leaves (Moringa oleifera) $(0.5 \mathrm{~g} / \mathrm{kg})$ and in sausages formulated with $500 \mathrm{ppm}$ of ethanolic extracts of green tea (Camellia sinensis L.) and nettle leaves (Urtica dioica L.).

Moisture and water activity $\left(\mathrm{a}_{\mathrm{w}}\right)$ also have a considerable influence on the stability of processed meat products since these parameters influence the development and metabolic activity of microorganisms, including the production of toxins and the rate of some chemical hydrolytic and enzymatic reactions. The initial percentage of $\mathrm{a}_{\mathrm{w}}$ of fresh meat used as raw material for the production of processed meat products varies between 0.996-0.997, making it the ideal medium for the growth of pathogenic bacteria. However, these values decrease considerably during the different processes to which the meat is subjected for the elaboration of processed meat products, such as maturation, salting, or dehydration [47]. In fact, these methods are used as a barrier technology to prevent microbial growth. The incorporation of natural extracts will or will not affect the $\mathrm{a}_{\mathrm{w}}$ depending on the way they are used. It has been observed that when they are used in the form of extracts, they do not significantly influence this parameter [48]. However, when they are included in the form of powders, they can interact with the free water in formulations, causing this parameter to decrease [35].

The protein content is another very important indicator since together with lipids, it determines the nutritional value of meat and meat products. Oxidative damage to proteins can lead to losses in nutritional and sensory quality, such as colour or flavour [29,45]. Myoglobin is the protein responsible for the red colour of muscle foods. When this comes in contact with atmospheric oxygen (oxymyoglobin), the colouration of meat becomes bright red, which is characteristic of fresh products and denotes good condition. In contrast, oxidation of myoglobin (metmyoglobin), produced mainly by low-oxygen pressures, leads to a brown colouration, indicating spoilage [29,31,42,49]. Natural antioxidants can slow down 
these reactions by inhibiting the formation of metmyoglobin. Ouerfelli et al. [8] observed that the application of hydroalcoholic extracts (0.7\%) of fresh leaves of Azadirachta indica $\mathrm{L}$. reduced metmyoglobin formation by $36.70 \%$ and limited the loss of colour in ground meat. On the other hand, polyphenolic extracts can also improve certain parameters that together indicate colour quality in meat and meat products, such as yellowness ( $b^{*}=+$ yellow $\left./-b l u e\right)$, redness $\left(\mathrm{a}^{*}=+\right.$ red $/$-green $)$, and lightness $\left(\mathrm{L}^{*}=+\right.$ light $/-$ dark $)[14,34]$. Redness $\left(\mathrm{a}^{*}\right)$ is an extremely important parameter because it can influence the purchase decision of consumers. It is estimated that when the values range between 4.6 and 10.8, the product is perceived as brown [17]. In this regard, a study that measured the influence of pitanga leaves (Eugenia uniflora) during the first 11 days of storage of pork patties showed that treated samples had a slower rate of decline in $a^{*}$ values, maintaining a desirable red colour longer [29].

An additional method to estimate nutritional deterioration in shelf life studies is to analyse the characteristics of the lipid profile of the formulations, which would be correlated with the formation of hydroperoxides [18]. Both the analysis of fatty acid and cholesterol profile as well as the formation of hydroperoxides in prototypes with phenolic extracts are performed by comparing samples treated with antioxidants and samples without antioxidants (control). This determines the degree to which the antioxidant retards lipid oxidation [17]. In general, it has been observed that lipid degradation occurs during storage for all products independently of the treatment to which they have been subjected (without antioxidants, with natural or synthetic antioxidants). However, samples treated with plant extracts have significantly less degradation [29].

The formation of hydroperoxides $(\mathrm{ROOH})$ is determined by the thiobarbituric acidreactive substance (TBARS) assay in which malonaldehyde (MDA), a highly reactive compound formed as a consequence of the autolysis of polyunsaturated fatty acids, reacts with thiobarbituric acid, generating a compound with an absorbance maximum at $532 \mathrm{~nm}[50,51]$. It has been established that when hydroperoxides reach the threshold of $2.5 \mathrm{mg}$ MDA/ $\mathrm{kg}$ sample, a loss of sensory quality and perception of oxidation can be detected by consumers [52]. A more restrictive level of deterioration $(0.6 \mathrm{mg} \mathrm{MDA} / \mathrm{kg})$ of the rancid flavour in meat products were established by Georgantelis et al. [53]. The results obtained by Nowak et al. [17] and Vargas-Sánchez et al. [51] showed that the action of polyphenolic compounds from plant leaves delayed lipid oxidation in processed meat products. These inhibitions can be up to $80 \%$, inhibiting lipid oxidation even more effectively than synthetic antioxidants, such as BHT and BHA [8,18,34]. Jayawardana et al. [15] observed that green and black tea (Camellia sinensis L.) leaf extracts are able to inhibit the formation of hydroperoxides by $67.4 \%$ and $65.2 \%$, respectively, while that of the synthetic antioxidant BHT was $49.7 \%$.

\subsection{Microbiological Changes}

Due to their high-protein nature, meat products are classified as highly perishable foods. Spoilage microorganisms (Pseudomonas, Lactobacillus, and Enterococcus) are responsible for the deterioration of meat products, and pathogenic bacteria (Salmonella enterica, Salmonella typhimurium, Staphylococcus aureus, Campylobacter jejuni, Escherichia coli, and Listeria monocytogenes) can put food safety at risk $[54,55]$. In order to provide safe food to consumers and to avoid microbial spoilage that can cause dramatic economic losses, the meat industry employs different barrier technologies to preserve these foods. Some of these technologies are the use of synthetic preservatives, curing, high pressures, modified atmosphere, ozone, pulsed electric fields, edible coatings or films, and lactic acid bacteria (LAB), among many others [56-59].

Natural extracts can also be incorporated as a potential source of bactericidal or bacteriostatic agents that can substitute other widely used technologies. Among the commonly used spices with powerful antimicrobial effect are the extracts of cilantro leaves (Coriandrum sativum), which showed an inhibitory effect on the growth of aerobic bacteria when they were applied to turkey meatballs (500 ppm). They inhibited the growth of gram-negative microorganisms, such as Salmonella choleraesuis spp., Campylobacter jejuni and Escherichia coli, probably due to contents of linalool in their essential oils $[27,60]$. Rosemary leaves (Salvia ros- 
marinus), applied at $1000 \mathrm{ppm}$ in turkey meatballs, limited the growth of psychotropic microorganisms, coliforms, and Clostridium [35]. Ali et al. [46] observed that tea leaf extracts (Camellia sinensis L.) also significantly reduced mesophilic and psychrotrophic bacteria counts when they were incorporated in chicken sausages (500 ppm). A similar behaviour was observed by Nowak et al. [17] in pork sausages, where Prunus cerasus L. and Ribes nigrum L. berry leaf extracts prevented the bacterial spoilage of mesophilic, psychrotrophic, LAB, and Brochothrix thermosphacta during 14 days of storage. According to Lorenzo et al. [29] and Rocchetti et al. [61], Eugenia uniflora leaf extracts (250 ppm) showed an inhibitory effect on Bacillus cereus, Escherichia coli, Pseudomonas aeruginosa, and Staphylococcus aureus when were applied to pork burgers. However, the most prominent effect was observed on Salmonella spp. In ground beef, Moringa oleifera leaf extracts had an inhibitory activity against Escherichia coli, Shigella flexinerii, Staphylococcus aureus, Staphylococcus epidermidis, Enterococcus faecalis, and Pseudomonas aeruginosa, while the extracts of cadillo leaves (Bidens pilosa) effectively inhibited the growth of Staphylococcus aureus, Staphylococcus epidermidis, Bacillus cereus, Enterococcus fecali, Escherichia coli, and Shigella flexinerii [62]. The phenolic compounds (gallic acid, caftaric acid, catechin, chlorogenic acid, epicatechin, and caffeic acid) present in the extracts obtained from Bidens pilosa are closely related to their antimicrobial effects. This is also reflected in the comparative studies carried out between the antimicrobial effects of n-hexane, ethyl acetate, and methanol extracts and reference drugs [63].

The high activity of the aforementioned extracts is related to their polyphenol contents. These bioactive compounds have the ability to interact with cell membrane proteins, causing a deformation in the structure and functionality of bacterial cell membranes. In addition, they affect electron transport and metabolic pathways for protein and nucleic acid synthesis [64]. The mechanisms of action of polyphenols on bacteria are illustrated in Figure 1. In the study mentioned above [62], Bacillus cereus and Serratia marcescens were resistant to the natural extracts of Moringa oliofera and Pseudomonas aeruginosa and Serratia marcescens to Bidens pilosa. According to the authors, the resistance of these strains could be related to the structure of the cell wall that restricts the penetration of the plant extracts. In this sense, it has been observed that gram-negative bacteria are more resistant to the attack of these compounds since their membrane is structurally more rigid [65]. It is also important to note that, like the antioxidant activity, the antimicrobial capacity of plant species can vary and is dependent on multiple factors, such as the type of plant, solvent used, extraction methods, concentration of extracts, and bacterial strain evaluated [43].

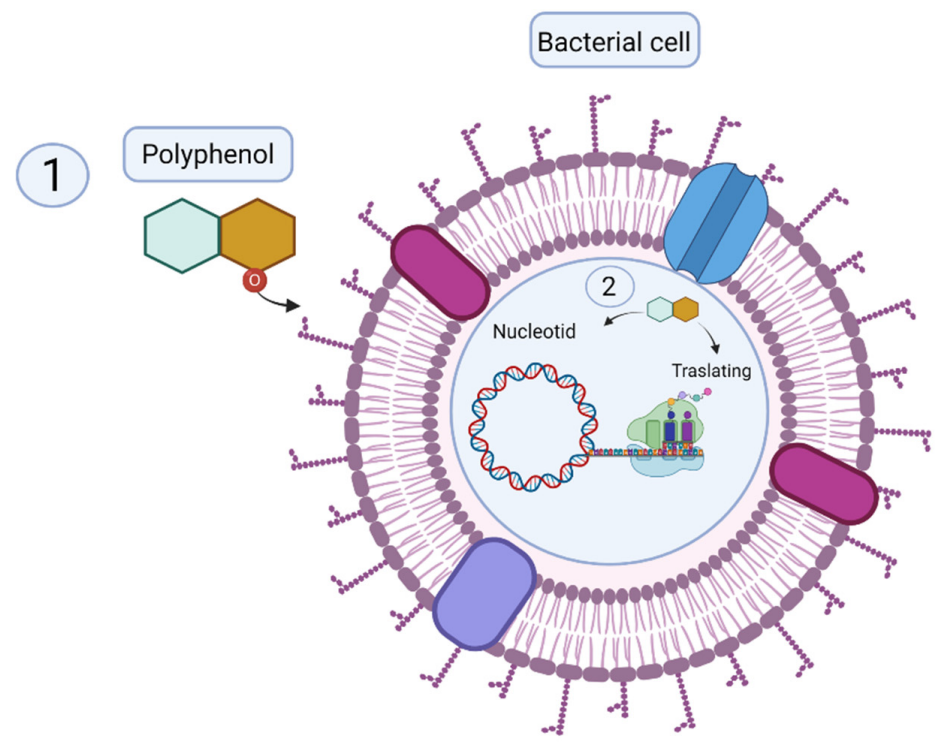

Figure 1. Antimicrobial mechanism of polyphenols. (1) The polyphenol molecule reacts with the proteins of the cell membrane of bacteria, causing lysis. (2) Inside the cell, it interferes with the synthesis of DNA and proteins, causing the death of the cell (created with BioRender.com, 3 July 2021). 


\subsection{Organoleptic Attributes}

In meat and processed meat products, the most visible characteristics that influence consumers' purchasing decisions are usually those most affected by oxidative deterioration. Oxidation of myoglobin and lipids, especially monounsaturated and polyunsaturated (which are the most exposed to oxidation due to their chemical nature), promote changes in colour and the appearance of volatile compounds (aldehydes, ketones, and alcohols), providing unpleasant odours and flavours to these products [2,42]. Numerous studies support the favourable effects of natural extracts on sensory quality attributes in processed meat products. General acceptability studies are carried out according to the criteria of consumers who identify the quality of prototypes using the parameters that are perceived through the senses when food is consumed (colour, flavour, odour, and texture) [9]. At the same time, there are very precise instrumental techniques that measure the formation of secondary metabolites from lipid oxidation through the formation of volatile compounds [66]. Although there are many lipid-derived products that contribute to the appearance of unpleasant odours in these products (aldehydes, alcohols, esters, furans, ketones, lactones, etc.), hexanal formation is considered the main indicator of lipid oxidation, determining changes in flavour and odour [2]. In this regard, the analysis of volatile compounds derived from lipid oxidation in lamb sausages with Curcuma longa L. extracts (250, 500, and $750 \mathrm{ppm})$ displayed the formation of aldehydes (hexanal, heptanal, octanal, 2-octenal) and alcohols (butanol, 1-pentanol, 1hexanol, 1-often-3-ol). Although these compounds were identified in all treatments (control, samples with sodium erythorbate, and samples with turmeric extracts), samples treated with turmeric extracts presented lower hexanal concentration at the beginning and at the end of storage. This finding was closely related to the sensory study conducted by consumers since the sausages with 250 and $750 \mathrm{ppm}$ of turmeric extracts maintained odour and good quality up to 12 days of storage. In contrast, the treatments without antioxidants and with sodium erythorbate were accepted only up to day 6 of storage [9]. These results are in agreement with those observed in beef pâté treated with natural extracts of bramble (Caesalpinia decapetala) leaves (500 ppm). The researchers pointed out the correlation between hexanal formation and TBARS values as a way to evaluate the development of lipid oxidation and the role of natural extracts in stabilizing oxidation reactions during storage [42]. Beal et al. [33] observed that sensory quality attributes (texture, colour, and overall acceptability) were not affected by the inclusion of bioactive extracts of mate leaves (Ilex paraguariensis St. Hil) in Italian-type sausage. Moreover, the best overall acceptability was observed after 60 days of storage. A similar effect was found by Nowak et al. [17] in sausages treated with cherry and currant leaf extracts. The authors observed that the extracts had no negative effects on sensory attributes, but sensory stability was improved compared to the control during 28 days of storage. In addition, neem (Azadirachta indica) leaf extracts (700 ppm) had a positive effect on the colour, aroma, acidity, and overall consumer acceptability of beef pâté [8].

\section{Aristotelia chilensis and Ugni molinae Leaves as Source of Natural Antioxidants} 4.1. Ugni molinae Turcz

Ugni molinae Turcz, commonly called "murtilla", "mutilla", or "murta", is a wild perennial shrub of the Myrtaceae family endemic to southern Chile. This evergreen shrub originates in the mountains of southern Chile and typically grows near the coastal and preAndean mountains between the regions of Maule and Los Lagos. Ugni molinae produces a globular red berry that is commonly consumed as a fresh fruit. Moreover, the infusions of its leaves are highly valued in Chilean indigenous folk medicine for the treatment of diarrhoea, dysentery, and urinary tract pain [19]. The mechanisms behind this phenomenon were unknown, but recent research has described them. Shene et al. [67] evaluated the bacterial growth in human faecal samples containing aqueous extracts of Ugni molinae Turcz leaves. The results showed that the aqueous extracts had prebiotic effects, favouring the growth of bacteria, such as Lactobacillus and Bifidobacteria, which demonstrates that these extracts can be used for therapeutic purposes. On the other hand, several studies also demonstrated the clinical properties of Ugni molinae Turcz leaves, concluding that 
leaf extracts increase plasma antioxidant capacity due to the high amounts of polyphenols identified [68]. In addition, they have an inhibitory effect on enzymes involved in glycaemic control, such as $\alpha$-amylase and $\alpha$-glucosidase [69].

Although the main commercial use of Ugni molinae Turcz is focused on the sale of marmalades, juice, or liquor [70,71], they have also been incorporated into cosmetics and pharmaceutical supplements. In addition, the food industry is studying the use of its extracts for the elaboration of edible films [72].

\subsubsection{Bioactive Compound Profile of Ugni molinae Turcz Leaves}

High-Performance Liquid Chromatography-Mass Spectrometry (HPLC-MS) analysis revealed the presence of a wide diversity of bioactive compounds in the leaves of Ugni molinae Turcz (Figure 2a).

a)

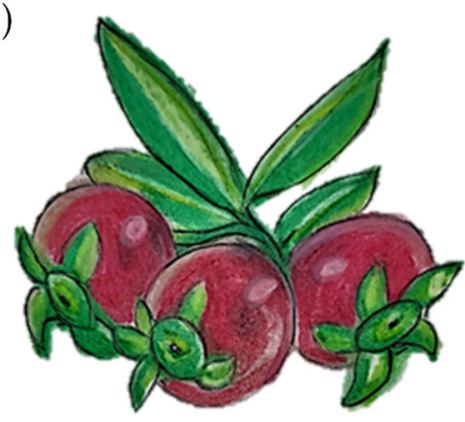

POLYPHENOLS

Ugni molinae

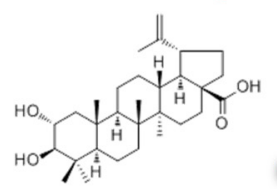

Alphitolic acid<smiles>O=C(O)/C=C/c1ccc(O)c(O)c1</smiles>

(4)

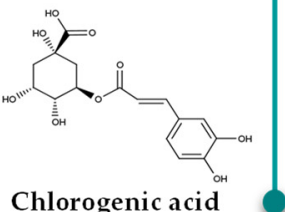

Chlorogenic acid

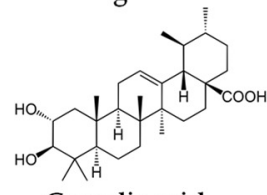

Crosolic acid

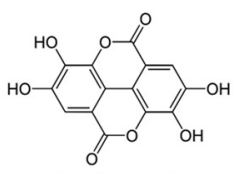

Ellagic acid

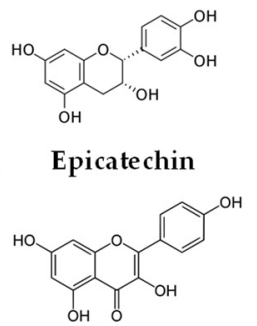

Kaempferol

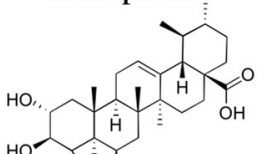<smiles>CC(CO)C1CCCC1CO</smiles>

Madecassic acid<smiles>OC/C=C/OCc1cc(O)c(O)c(O)c1</smiles>

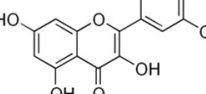

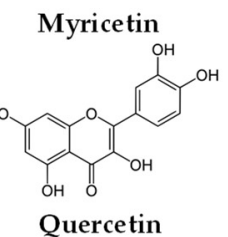

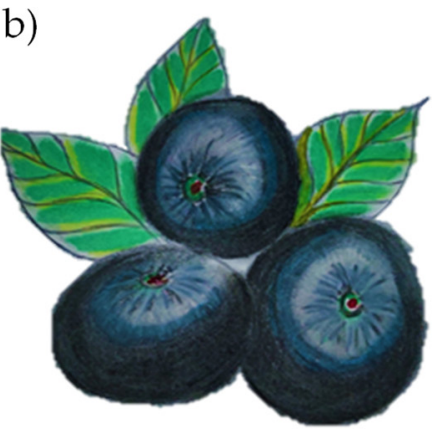

ALKALOIDS AND POLYPHENOLS Aristotelia chilensis<smiles>C[C@@H]1C[C@@]2(C)c3[nH]c4ccccc4c3C[C@@H]2NC1(C)C</smiles>

Aristoteline<smiles>CC1=CC[C@H](C)C(C)(C)N[C@H]1c1ccnc2ccccc12</smiles>
Aristoquinoline<smiles>CC1(C)N[C@H]2C(=O)c3c([nH]c4ccccc34)[C@H]3CC[C@H](C[C@H]32)C1(C)C</smiles>
Aristotelinone<smiles>CC1=CC[C@@H]2C[C@H]1[C@@H](Cc1c[nH]c3ccccc13)NC2(C)C</smiles>

Hobartine

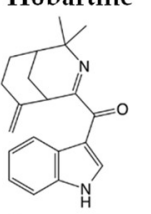

8-0xo-9dehydromakomakine<smiles></smiles>

Catechin<smiles>O=C(O)c1cc(O)c(O)c(O)c1</smiles>

Gallic acid<smiles></smiles>

Kaempferol<smiles></smiles>

Pelargonidin<smiles>O=c1c(O)c(-c2ccc(O)c(O)c2)oc2cc(O)cc(O)c12</smiles>

Quercetin

Figure 2. Main bioactive compounds present in the leaves of Ugni molinae Turcz (a) and Aristotelia chilensis (b) [73-76].

Among the compounds identified are kaempferol, which is a flavonol biosynthesized from naringenin (flavone) in the presence of the enzyme flavone 3-hydroxylase [77]. In 
addition, ninety-two different compounds have been reported in ethanolic extracts of Ugni molinae Turcz leaves, with the main ones as follows: gallic acid, myricetin, myricetin glucoside, myricetin hexoside, myricetin rhamnoside, myricetin dirhamnoside, quercetin, quercetin hexoside, quercetin rhamnoside, quercetin dirhamnoside, quercetin glucoside, epicatechin, and kaempferol glucoside. In the aqueous extracts, in addition to the abovementioned compounds, gallic acid derivative, myricetin xyloside, and quercetin xyloside were found, although in a lower concentration. Additionally, Ugni molinae Turcz leaves are rich in triterpene acids, such as apostolic acid, corosolic acid, asiatic acid, betulinic acid, oleanolic acid, ursolic acid, medacassic acid, ellagic acid, chlorogenic acid, gallic acid, and caffeic acid. In summary, the polyphenols present in Ugni molinae Turcz leaves can be divided into flavonol glycosides, non-glycoside flavanols, and triterpenoids $[68,71,78]$.

Several researchers have reported that polyphenolic concentration and composition are variable depending on the different fractions. In this regard, Shene et al. [67] reported that the extraction with 50/50 $(v / v)$ ethanol/water allows a higher release of polyphenols compared to the extraction with water (8406 and $6876 \mathrm{mg}$ GAE/L, respectively). According to the authors, this is due to the high capacity of low-polarity solvents to extract specific phenolic compounds. Studies conducted by Rubilar et al. [79] and López de Dicastillo et al. [25] on Ugni molinae Turcz leaf extracts showed that a higher yield of flavonoid glycosides, such as quercetin 3-O-glucoside, quercetin 3-O-rhamnoside, and gallic acid and its derivatives, are obtained in water, while flavonols, such as catechin hydrate and ellagic acid, are extracted exclusively by alcohols. In addition, ArancibiaRadich et al. [68] observed considerably higher total polyphenols (PT) levels in ethanolic extracts obtained from leaves of 10 different genotypes of Ugni molinae than those extracted with ethyl acetate (157.6-225.8 and 36.1-92.3 mg GAE/g extract, respectively). In crude extracts of Ugni molinae Turcz leaves, the PT concentration found was higher than those obtained in other plant matrices that have already been used for the elaboration of meat products (634.6 mg GAE/g of lyophilized extract vs. 229.38, 3.17 and $2.17 \mathrm{mg}$ GAE/g for Ugni molinae Turcz, pitanga, cherry, and currant leaves, respectively) $[17,29,80]$.

\subsubsection{Antioxidant and Antimicrobial Capacity of Ugni molinae Turcz Leaves}

In this review, the use of leaves is highlighted because several authors have reported that they present higher PT levels and therefore higher antioxidant and antimicrobial capacity. The leaves of Ugni molinae Turcz have PT concentrations four-times higher than its fruits (6.81 vs. $2.32 \mathrm{mg} / \mathrm{g}$ for leaves and fruit, respectively). Similarly, the antioxidant capacities of the plant suggest the same tendencies (361 vs. $110 \mathrm{mg}$ Trolox/g for leaves and fruit, respectively) [25]. Indeed, a Pearson correlation analysis confirmed a significant positive correlation between PT concentration and antioxidant activity, with a higher correlation for the Trolox equivalent antioxidant capacity (TEAC) and 2,2-diphenyl-1picrylhydrazyl radical scavenging activity (DPPH) [25]. In addition, Rubilar et al. [69] found that the leaves had higher PT concentration than fruits and stems $(32.5,15.8$, and $10.1 \mathrm{mg} \mathrm{GAE} / \mathrm{g}$ for leaves, stems, and fruits, respectively), which results in a higher antioxidant activity. In this regard, the concentration of crude extract of Ugni molinae Turcz leaves required to inhibit 50\% of DPPH was two- and four-times lower than that needed by stems and fruits, respectively.

About antimicrobial activity, several authors reported that Ugni molinae Turcz leaf extracts have antimicrobial activity on Escherichia coli, Listeria monocytogenes, Bacillus subtilis, Micrococcus luteus, Staphylococcus aureus, Staphylococcus epidermidis, Pseudomonas aeruginosa, Enterobacter aerogenes, and Candida albicans [25,72,81]. Moreover, phenolic extracts of Ugni molinae leaves incorporated into edible films inhibited the growth of Listeria innocua up to 60 days after storage. These antimicrobial effects are associated with the presence of quercetin in the leaves of Ugni molinae [72]. In addition, they promote the growth of beneficial bacteria, such as Lactobacillus and Bifidobacteria [67]. However, there is still very little information on the minimum inhibitory concentration (MIC) 
and minimum bactericidal concentration (MBC) of these extracts to inhibit the growth of pathogenic bacteria.

\subsection{Aristotelia chilensis (Mol.) Stuntz}

Aristotelia chilensis is an evergreen tree belonging to the Eleocarpaceae family. The genus Aristotelia is represented by five species that are distributed in the South Pacific region (Chile, Argentina, New Zealand, Australia, and Tasmania Island). In Chile, this plant, commonly known as maqui, has a geographical distribution that goes from Limarí (IV Region) to Aysén (XI Region). It grows mainly in humid soils of the central valley, on the mountain slopes, ravines, or forest margins from near sea level up to an altitude of $2500 \mathrm{~m}$. Its fruit is a round, fleshy, and dark violet edible berry [82,83]. Its leaves and stems have been traditionally used by indigenous peoples as phytotherapy to prevent or cure some ailments, such as fever, inflammations, dysentery, and haemorrhages [84]. Recent studies have shown that the antioxidant, antidepressant, anti-inflammatory, and anticarcinogenic capacity of this plant are the result of the high biological activity of its compounds at the cellular level $[74,85]$. Some of these compounds are caffeic acid, ferulic acid, and protopine (isoquinoline alkaloid), which are identified as possibly responsible for the analgesic effect of Aristotelia chilensis leaves [84]. Furthermore, Ojeda et al. [86] demonstrated that Aristotelia chilensis extracts can reduce the expression of cyclooxygenase 2 (COX-2), preventing the inflammation in colon cancer cells. The alkaloid fraction present in the leaves of this plant (aristothelin and 8-Oxo-9-dihydromakomachin) is considered to have vasodilatory effects on vascular tissues, suggesting that it could be very useful in treating diseases, such as hypertension $[87,88]$. Furthermore, research in murine models indicated that anthocyanin-rich extracts of Aristotelia chilensis act on lipid metabolism by lowering lowdensity lipoprotein (LDL) levels in the blood and on carbohydrate metabolism due to their anti-diabetic activity $[89,90]$.

The fruit of Aristotelia chilensis, besides being consumed, is commonly used in Chile as raw material for the artisanal production of marmalades and preserves. At the industrial level, it is used for the production of natural colourants, ice cream, marmalades, and juices [22,91]. In the pharmaceutical industry, several formulations made from the fruit of Aristotelia chilensis have been patented (Delphinol ${ }^{\circledR}$, MaquiBright ${ }^{\circledR}$, among others) $[21,92]$. Its leaves are used as an unguent, as an infusion to cure throat diseases, intestinal tumours, and to wash out mouth ulcers [82]. The Chilean Ministry of Health's list of traditional herbal medicines approves the use of Aristotelia chilensis leaves to relieve diarrhoea, dysentery, colds, sore throats, inflammation of the tonsils, and mouth ulcers [93]. All these benefits of the Aristotelia chilensis plant as a superfood have generated a worldwide demand [94]. Currently, 19 companies are exporting Aristotelia chilensis to 9 countries among which South Korea stands out, with more than $80 \%$ of the national production (104,000 tonnes) [83]. However, the by-products generated are not utilised yet despite being a rich source of natural compounds that could be used for the production of value-added products based on sustainable technologies.

\subsubsection{Bioactive Compound Profile of Aristotelia chilensis Leaves}

Although the fruits of $A$. chilensis are valued for their high concentrations of polyphenols among which anthocyanins stand out [95], its leaves have a higher concentration and variety of bioactive compounds [69]. In this regard, the leaves of Aristotelia chilensis are a source of alkaloids (airstone, aristotelone, aristotelone, aristotelinin, hobartine, makonine, 8-oxo-9 dehydrohobartin, and 8-oxo-9 dehydromakomachin), anthocyanins (pelargonidin $(14.45 \%)$ and peonidin $(0.20 \%)$ ), flavonols (catechin $(21.75 \%)$, quercetin $(1.3 \%)$, isoquercitrin $(0.35 \%)$, myricetin $(2.26 \%)$, rutin $(1.79 \%)$, and kaempferol)), phenolic acids (gallic acid $(47.55 \%)$ and coumaric acid $(6.81 \%))$, and stilbenes (resveratrol $(3.55 \%))[69,96,97]$ (Figure $2 \mathrm{~b}$ ). This wide diversity of bioactive compounds provides a high antioxidant capacity to the plant. However, it must be taken into account that both the photochemical composition and the antioxidant capacity will be influenced by biotic and abiotic factors 
surrounding the plant. A very significant biotic factor is usually the genotype and age of the plant $[94,98]$. Thus, it has been observed that the capacity of Aristotelia chilensis to synthesize anthocyanins varies in young leaves and fully expanded leaves, the latter having a higher concentration of anthocyanins [99]. Abiotic factors are usually influenced by the geographical area and climatic conditions, including solar radiation, humidity, temperature, altitude, water and microbial interactions, soil fertility, and harvest year [96,98]. Considering the above, the climatic conditions under which this plant grows could explain its high concentrations of phytochemicals. Its presence is common in the foothills of the Andes, which are under constant abiotic stress caused by the humidity and cold temperatures typical of this type of climate. This causes a metabolic imbalance that can cause cellular oxidative stress, forcing the plant to produce greater amounts of bioactive compounds [82].

\subsubsection{Antioxidant and Antimicrobial Capacity of Aristotelia chilensis Leaves}

In meat and meat products, lipid degradation, proteolysis, and microbiological contamination lead to rancidity and changes of colour, flavour, and reduction of shelf life $[2,100]$. These changes occur when these foods are subjected to changing conditions, such as exposure to oxygen, high temperature, and light during their storage as well as the presence of catalytic agents, such as iron $[8,50]$. In particular, fatty acids are the most susceptible to oxidative degradation and, within this, polyunsaturated acids (PUFA) due to the several double bonds present in their carbon chain are the most susceptible to oxidative degradation [2,101]. In these phases, the presence of natural antioxidants, which prevent or delay the formation of free radicals, is essential. The mechanisms responsible for the antioxidant capacity of these natural extracts are diverse. However, it is well known that the antioxidant richness of natural extracts is proportional to the concentration of bioactive molecules present in them and the interactions between these molecules and the main mechanisms described in food, which involve the transfer of a proton or an electron to a free radical molecule (Figure 3) [25].

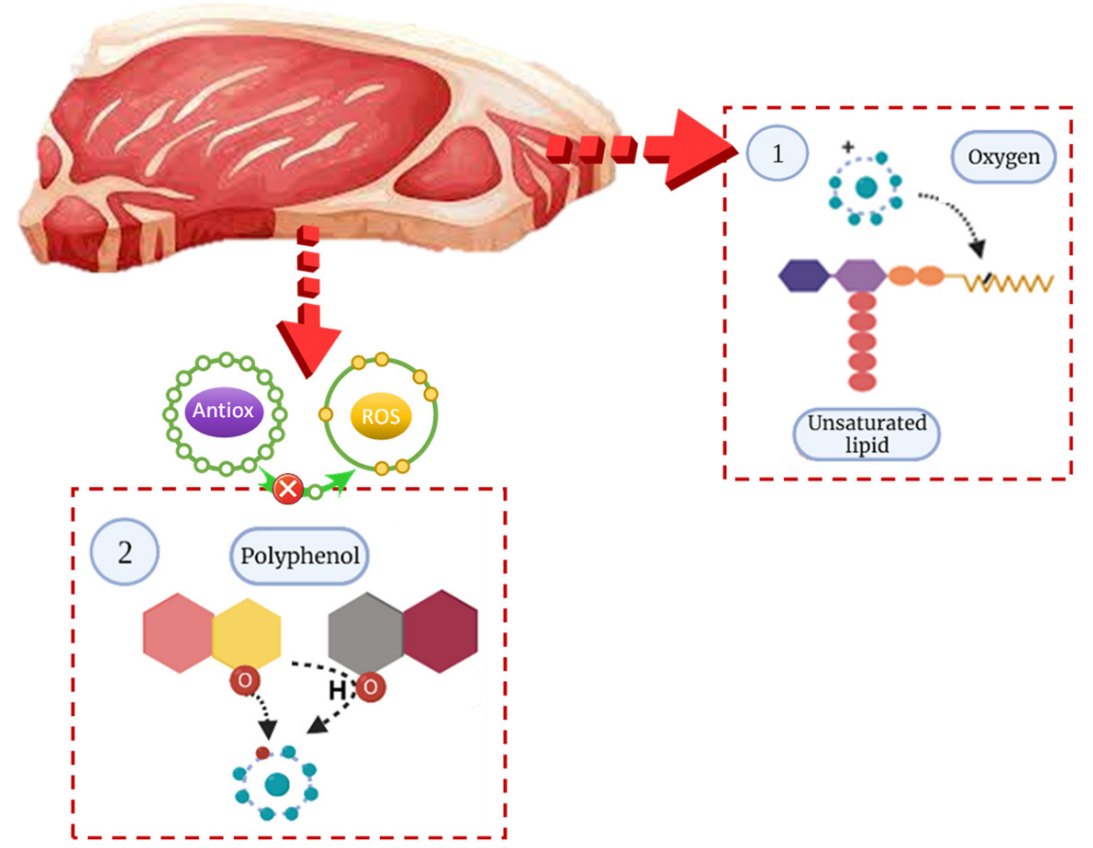

Figure 3. Antioxidant mechanisms of polyphenols. (1) Oxygen or reactive oxygen species, deficient in electrons, react with the double bonds of the carbon chains of fatty acids. (2) Polyphenol molecule transfers an electron or a proton to the reactive oxygen species, stabilizing it and preventing it from reacting with the fatty acids (created with BioRender.com, 3 July 2021).

Natural extracts of Aristotelia chilensis leaves show a high polyphenolic concentration and antioxidant activity in all their derived fractions. Moreover, it was also evidenced that 
the presence of different classes of bioactive compounds varied depending on whether methanol, hexane, dichloromethane, or water was used. In this sense, Rubilar et al. [69] reported that the PT concentration of the crude extract obtained from Aristotelia chilensis leaves using $50 \%(v / v)$ ethanol and a solvent-to-solid ratio (5:1) was $69.0 \mathrm{mg} \mathrm{GAE} / \mathrm{g}$, while contents of 15.9 and $5.6 \mathrm{mg} \mathrm{GAE} / \mathrm{g}$ were obtained in the aqueous and organic-aqueous fractions, respectively. Moreover, this study showed that independently of the solvent used for the extraction, leaves had a higher concentration of polyphenols than fruits and stems. Other studies confirmed that when a higher concentration of ethanol was used in the hydroalcoholic mixture (60:40) with a solvent-to-solid ratio (6:1), a higher concentration of PT ( $40 \mathrm{mM} \mathrm{EAG)} \mathrm{was} \mathrm{found.} \mathrm{The} \mathrm{same} \mathrm{trend} \mathrm{was} \mathrm{observed} \mathrm{in} \mathrm{the} \mathrm{antioxidant} \mathrm{capacity}$ of Aristotelia chilensis leaf extracts. DPPH method displayed values of 158.2 and $189.5 \mathrm{mM}$ EAG for extracts at $0.1 \%$ and $1 \%$, respectively, while ABTS method showed values of 165.1 and $165.7 \mathrm{mM} \mathrm{EAG}$ for extracts at $0.1 \%$ and $1 \%$, respectively [97]. Additionally, according to Muñoz et al. [84], the antioxidant activity of Aristotelia chilensis leaf extracts against DPPH radical inhibition is higher when water or methanol are used as extraction solvents (12.1 and $9.7 \mu \mathrm{g} / \mathrm{mL}$, respectively). In the same way, Avello et al. [102] reported that aqueous extracts of Aristotelia chilensis leaves had a PT concentration lower than those observed in hydroalcoholic extracts ( 0.032 vs. $0.040 \mathrm{M} \mathrm{EAG}$, respectively). However, $100 \%$ inhibition was observed in DPPH (6.0-0.6 $\mu \mathrm{M}$ EAG) for all extracts.

Likewise, the high antioxidant activity of Aristotelia chilensis leaf extracts, expressed as $\mathrm{IC}_{50}(8.0,26.9$, and $29.4 \mathrm{mg}$ extract/L for crude extracts, aqueous, and organic-aqueous fraction, respectively), was also corroborated [69]. According to the authors, the required concentration of crude Aristotelia chilensis leaf extract to inhibit 50\% of DPPH was five-times lower than that needed by stem and 50-times lower than that of crude fruit extracts. However, it should be noted that with the use of solvents, it is difficult to obtain a polyphenolic yield of $100 \%$ compared to the use of powders. Furthermore, it must be taken into account that methanol is not a useful solvent for biological purposes. Therefore, food studies with Aristotelia chilensis leaf powders should be carried out as a way to increase yield, reduce production costs, and offer consumers functional and chemical-free foods.

Regarding the antimicrobial activity of Aristotelia chilensis leaves, it was found that there is little information on their antimicrobial properties. There was only one study carried out by Avello et al. [102] where ethanolic extracts (60\%) of Aristotelia chilensis leaves showed an inhibitory effect on Pseudomonas aeruginosa, Enterobacter aerogenes, Staphylococcus aureus, and the fungus Candida albicans.

\section{Conclusions}

Currently, polyphenols are of great interest to the meat industry because they may have antioxidant and antimicrobial activity that is equal or superior to synthetic antioxidants. Their incorporation into meat products can improve their stability and extend the shelf life of these highly perishable foods. Furthermore, there is sufficient scientific evidence that confirms the association between their regular consumption and the prevention of various chronic diseases, such as inflammation, cancer, diabetes, and Alzheimer's disease. Aristotelia chilensis and Ugni molinae Turcz are two endemic plants from Chile with great potential to be used in meat formulations. They distinguish themselves from other fruits and plant species due to their high polyphenolic concentration and in-vitro antioxidant activity. In particular, the leaves of both plants (especially the raw fractions or powders) have higher variety and levels of bioactive compounds, which could be used for the creation of new value-added meat formulations, which demonstrate that the by-products of the agricultural industry can be used as a source of natural antioxidants and antimicrobials. Moreover, many studies have been carried out to characterize the phenolic composition of these plants and their clinical effects. However, little research was found on the antimicrobial potency and, in particular, in MIC and MBC of Aristotelia chilensis leaf extracts. In addition, it is necessary to carry out studies in which the extracts of the leaves of Ugni molinae Turcz and Aristotelia chilensis are incorporated into meat formulations. The evaluation of the effect of these natural extracts on 
physicochemical, microbiological, and organoleptic parameters will allow to corroborate their great potential as antioxidants and antimicrobials.

Author Contributions: Conceptualization, J.M.L. and N.S.; writing-original draft preparation, L.V. and R.D.; writing-Figure's design, review, and editing, J.Q., M.P., J.M.L. and N.S.; supervision, J.M.L. and N.S. All authors have read and agreed to the published version of the manuscript.

Funding: This research was funded by CYTED (reference 119RT0568).

Institutional Review Board Statement: Not applicable.

Informed Consent Statement: Not applicable.

Data Availability Statement: Not applicable.

Acknowledgments: L.V. would like to thank the Dirección de Postgrado, Programa de Doctorado en Ciencias Agroalimentarias y Medioambiente, Universidad de La Frontera and National Doctoral Grant ANID N²1210093. J.Q. would like to thank the project FONDECYT N³190287. R.D. would like to thank the project FONDECYT N 11190621 Thanks to GAIN (Axencia Galega de Innovación) for supporting this review (grant number IN607A2019/01). The authors (J.M.L., M.P. and N.S.) are members of the Healthy Meat network, funded by CYTED (reference 119RT0568).

Conflicts of Interest: The authors declare no conflict of interest.

\section{References}

1. Horita, C.N.; Baptista, R.C.; Caturla, M.Y.R.; Lorenzo, J.M.; Barba, F.J.; Sant'Ana, A.S. Combining reformulation, active packaging and non-thermal post-packaging decontamination technologies to increase the microbiological quality and safety of cooked ready-to-eat meat products. Trends Food Sci. Technol. 2018, 72, 45-61. [CrossRef]

2. Domínguez, R.; Pateiro, M.; Gagaoua, M.; Barba, F.J.; Zhang, W.; Lorenzo, J.M. A comprehensive review on lipid oxidation in meat and meat products. Antioxidants 2019, 8, 429. [CrossRef] [PubMed]

3. Lorenzo, J.M.; Carballo, J. Changes in physico-chemical properties and volatile compounds throughout the manufacturing process of dry-cured foal loin. Meat Sci. 2015, 99, 44-51. [CrossRef] [PubMed]

4. Bermúdez, R.; Franco, D.; Carballo, J.; Lorenzo, J.M. Influence of type of muscle on volatile compounds throughout the manufacture of Celta dry-cured ham. Food Sci. Technol. Int. 2015, 21, 581-592. [CrossRef]

5. Efenberger-Szmechtyk, M.; Nowak, A.; Czyzowska, A. Plant extracts rich in polyphenols: Antibacterial agents and natural preservatives for meat and meat products. Crit. Rev. Food Sci. Nutr. 2020, 61, 149-178. [CrossRef]

6. Schnettler, B.; Sepúlveda, N.; Bravo, S.; Grunert, K.G.; Hueche, C. Consumer acceptance of a functional processed meat product made with different meat sources. Br. Food J. 2018, 120, 424-440. [CrossRef]

7. Hung, Y.; de Kok, T.M.; Verbeke, W. Consumer attitude and purchase intention towards processed meat products with natural compounds and a reduced level of nitrite. Meat Sci. 2016, 121, 119-126. [CrossRef]

8. Ouerfelli, M.; Villasante, J.; Ben Kaâb, L.B.; Almajano, M. Effect of neem (Azadirachta indica L.) on lipid oxidation in raw chilled beef patties. Antioxidants 2019, 8, 305. [CrossRef] [PubMed]

9. de Carvalho, F.A.L.; Munekata, P.E.S.; Lopes de Oliveira, A.; Pateiro, M.; Domínguez, R.; Trindade, M.A.; Lorenzo, J.M. Turmeric (Curcuma longa L.) extract on oxidative stability, physicochemical and sensory properties of fresh lamb sausage with fat replacement by tiger nut (Cyperus esculentus L.) oil. Food Res. Int. 2020, 136, 109487. [CrossRef]

10. Munekata, P.E.S.; Rocchetti, G.; Pateiro, M.; Lucini, L.; Domínguez, R.; Lorenzo, J.M. Addition of plant extracts to meat and meat products to extend shelf-life and health-promoting attributes: An overview. Curr. Opin. Food Sci. 2020, 31, 81-87. [CrossRef]

11. Luo, A.; Feng, J.; Hu, B.; Lv, J.; Chen, C.-Y.O.; Xie, S. Polysaccharides in Spirulina platensis Improve Antioxidant Capacity of Chinese-Style Sausage. J. Food Sci. 2017, 82, 2591-2597. [CrossRef]

12. Al-Hijazeen, M. Effect of direct adding oregano essential oil (Origanum syriacum L.) on quality and stability of chicken meat patties. Food Sci. Technol. 2018, 38, 123-130. [CrossRef]

13. Ramírez-Rojo, M.I.; Vargas-Sánchez, R.D.; del Mar Torres-Martínez, B.; Torrescano-Urrutia, G.R.; Sánchez-Escalante, A. Extractos de hojas de plantas para conservar la calidad de la carne y los productos cárnicos frescos. Revisión. Biotecnia 2018, 20, 155-164. [CrossRef]

14. Alirezalu, K.; Hesari, J.; Eskandari, M.H.; Valizadeh, H.; Sirousazar, M. Effect of Green Tea, Stinging Nettle and Olive Leaves Extracts on the Quality and Shelf Life Stability of Frankfurter Type Sausage. J. Food Process. Preserv. 2017, 41, e13100. [CrossRef]

15. Jayawardana, B.C.; Warnasooriya, V.B.; Thotawattage, G.H.; Dharmasena, V.A.K.I.; Liyanage, R. Black and green tea (Camellia sinensis L.) extracts as natural antioxidants in uncured pork sausages. J. Food Process. Preserv. 2019, 43, e13870. [CrossRef]

16. Borella, T.G.; Peccin, M.M.; Mazon, J.M.; Roman, S.S.; Cansian, R.L.; Soares, M.B.A. Effect of rosemary (Rosmarinus officinalis) antioxidant in industrial processing of frozen-mixed hamburger during shelf life. J. Food Process. Preserv. 2019, 43, 43. [CrossRef]

17. Nowak, A.; Czyzowska, A.; Efenberger, M.; Krala, L. Polyphenolic extracts of cherry (Prunus cerasus L.) and blackcurrant (Ribes nigrum L.) leaves as natural preservatives in meat products. Food Microbiol. 2016, 59, 142-149. [CrossRef] 
18. Burri, S.C.M.; Granheimer, K.; Rémy, M.; Ekholm, A.; Håkansson, Å.; Rumpunen, K.; Tornberg, E. Lipid Oxidation Inhibition Capacity of 11 Plant Materials and Extracts Evaluated in Highly Oxidised Cooked Meatballs. Foods 2019, 8, 406. [CrossRef] [PubMed]

19. Vega-Galvez, A.; Rodríguez, A.; Stucken, K. Antioxidant, functional properties and health-promoting potential of native South American berries: A review. J. Sci. Food Agric. 2021, 101, 364-378. [CrossRef]

20. Lorenzo, J.M.; Pateiro, M.; Domínguez, R.; Barba, F.J.; Putnik, P.; Kovačević, D.B.; Shpigelman, A.; Granato, D.; Franco, D. Berries extracts as natural antioxidants in meat products: A review. Food Res. Int. 2018, 106, 1095-1104. [CrossRef] [PubMed]

21. Yamashita, S.I.; Suzuki, N.; Yamamoto, K.; Iio, S.I.; Yamada, T. Effects of MaquiBright ${ }^{\circledR}$ on improving eye dryness and fatigue in humans: A randomized, double-blind, placebo-controlled trial. J. Tradit. Complement. Med. 2019, 9, 172-178. [CrossRef]

22. Salar, F.J.; Agulló, V.; García-Viguera, C.; Domínguez-Perles, R. Stevia vs. Sucrose: Influence on the Phytochemical Content of a Citrus-Maqui Beverage-A Shelf Life Study. Foods 2020, 9, 219. [CrossRef]

23. Rodríguez, L.; Trostchansky, A.; Wood, I.; Mastrogiovanni, M.; Vogel, H.; González, B.; Maróstica Junior, M.; Fuentes, E.; Palomo, I. Antiplatelet activity and chemical analysis of leaf and fruit extracts from Aristotelia chilensis. PLoS ONE 2021, 16, e0250852. [CrossRef]

24. Pateiro, M.; Barba, F.J.; Domínguez, R.; Sant'Ana, A.S.; Mousavi Khaneghah, A.; Gavahian, M.; Gómez, B.; Lorenzo, J.M. Essential oils as natural additives to prevent oxidation reactions in meat and meat products: A review. Food Res. Int. 2018, 113, 156-166. [CrossRef]

25. López de Dicastillo, C.; Bustos, F.; Valenzuela, X.; López-Carballo, G.; Vilariño, J.M.; Galotto, M.J. Chilean berry Ugni molinae Turcz. fruit and leaves extracts with interesting antioxidant, antimicrobial and tyrosinase inhibitory properties. Food Res. Int. 2017, 102, 119-128. [CrossRef] [PubMed]

26. Ramírez-Rojo, M.I.; Vargas-Sánchez, R.D.; del Mar Torres-Martínez, B.; Torrescano-Urrutia, G.R.; Lorenzo, J.M.; Sánchez-Escalante, A. Inclusion of ethanol extract of mesquite leaves to enhance the oxidative stability of pork patties. Foods 2019, 8, 631. [CrossRef] [PubMed]

27. Gantner, M.; Guzek, D.; Najda, A.; Brodowska, M.; Górska-Horczyczak, E.; Wojtasik-Kalinowska, I.; Godziszewska, J. Oxidative and microbial stability of poultry meatballs added with coriander extracts and packed in cold modified atmosphere. Int. J. Food Prop. 2017, 20, 2527-2537. [CrossRef]

28. Van Hecke, T.; Ho, P.L.; Goethals, S.; De Smet, S. The potential of herbs and spices to reduce lipid oxidation during heating and gastrointestinal digestion of a beef product. Food Res. Int. 2017, 102, 785-792. [CrossRef]

29. Lorenzo, J.M.; Vargas, F.C.; Strozzi, I.; Pateiro, M.; Furtado, M.M.; Sant'Ana, A.S.; Rocchetti, G.; Barba, F.J; Dominguez, R.; Lucini, L.; et al. Influence of pitanga leaf extracts on lipid and protein oxidation of pork burger during shelf-life. Food Res. Int. 2018, 114, 47-54. [CrossRef]

30. Mancuso, G.; Borgonovo, G.; Scaglioni, L.; Bassoli, A. Phytochemicals from Ruta graveolens Activate TAS2R Bitter Taste Receptors and TRP Channels Involved in Gustation and Nociception. Molecules 2015, 20, 18907-18922. [CrossRef]

31. Pateiro, M.; Vargas, F.C.; Chincha, A.A.I.A.; Sant'Ana, A.S.; Strozzi, I.; Rocchetti, G.; Barba, F.J.; Domínguez, R.; Lucini, L.; do Amaral Sobral, P.J.; et al. Guarana seed extracts as a useful strategy to extend the shelf life of pork patties: UHPLC-ESI/QTOF phenolic profile and impact on microbial inactivation, lipid and protein oxidation and antioxidant capacity. Food Res. Int. 2018, 114, 55-63. [CrossRef]

32. Falowo, A.B.; Muchenje, V.; Hugo, A.; Aiyegoro, O.A.; Fayemi, P.O. Antioxidant activities of Moringa oleifera L. and Bidens pilosa L. leaf extracts and their effects on oxidative stability of ground raw beef during refrigeration storage. CyTA J. Food 2017, 15, 249-256. [CrossRef]

33. Beal, P.; Faion, A.M.; Cichoski, A.J.; Cansian, R.L.; Valduga, A.T.; De Oliveira, D.; Valduga, E. Oxidative stability of fermented Italian-type sausages using mate leaves (Ilex paraguariensis St. Hil) extract as natural antioxidant. Int. J. Food Sci. Nutr. 2011, 62, 703-710. [CrossRef]

34. Hać-Szymańczuk, E.; Cegiełka, A.; Chmiel, M.; Czaja, K. Antioxidant and Antimicrobial Effects of Oregano on Quality Characteristics of Model Pork Batters. J. Food Process. Preserv. 2017, 41, e12796. [CrossRef]

35. Karpińska-Tymoszczyk, M. Effect of the addition of ground rosemary on the quality and shelf-life of turkey meatballs during refrigerated storage. Br. Poult. Sci. 2008, 49, 742-750. [CrossRef]

36. Mahdavian Mehr, H.; Hosseini, Z.; Haddad Khodaparast, M.H.; Edalatian, M.R. Study on the antimicrobial effect of Salvia leriifolia (Nowroozak) leaf extract powder on the growth of staphylococcus aureus in hamburger. J. Food Saf. 2010, 30, 941-953. [CrossRef]

37. Boruzi, A.I.; Nour, V. Antioxidant effects of walnut leaves and sweet cherry stems on color, lipid oxidation and sensory quality of cooked pork patties. Not. Bot. Horti Agrobot. Cluj-Napoca 2019, 47, 763-771. [CrossRef]

38. Alirezalu, K.; Pateiro, M.; Yaghoubi, M.; Alirezalu, A.; Peighambardoust, S.H.; Lorenzo, J.M. Phytochemical constituents, advanced extraction technologies and techno-functional properties of selected Mediterranean plants for use in meat products. A comprehensive review. Trends Food Sci. Technol. 2020, 100, 292-306. [CrossRef]

39. Quispe-Fuentes, I.; Vega-Gálvez, A.; Campos-Requena, V. Antioxidant Compound Extraction from Maqui (Aristotelia chilensis [Mol] Stuntz) Berries: Optimization by Response Surface Methodology. Antioxidants 2017, 6, 10. [CrossRef] 
40. Khawli, F.A.; Pateiro, M.; Domínguez, R.; Lorenzo, J.M.; Gullón, P.; Kousoulaki, K.; Ferrer, E.; Berrada, H.; Barba, F.J. Innovative green technologies of intensification for valorization of seafood and their by-products. Mar. Drugs 2019, 17, 689. [CrossRef] [PubMed]

41. Bastías-Montes, J.M.; Monterrosa, K.; Muñoz-Fariña, O.; García, O.; Acuña-Nelson, S.M.; Vidal-San Martín, C.; Quevedo-Leon, R.; Kubo, I.; Avila-Acevedo, J.G.; Domiguez-Lopez, M.; et al. Chemoprotective and antiobesity effects of tocols from seed oil of Maqui-berry: Their antioxidative and digestive enzyme inhibition potential. Food Chem. Toxicol. 2020, 136, 111036. [CrossRef]

42. Gallego, M.; Gordon, M.; Segovia, F.; Almajano, M. Caesalpinia decapetala Extracts as Inhibitors of Lipid Oxidation in Beef Patties. Molecules 2015, 20, 13913-13926. [CrossRef]

43. Alcántara, C.; Žugčić, T.; Abdelkebir, R.; García-Pérez, J.V.; Jambrak, A.R.; Lorenzo, J.M.; Collado, M.C.; Granato, D.; Barba, F.J. Effects of Ultrasound-Assisted Extraction and Solvent on the Phenolic Profile, Bacterial Growth, and AntiInflammatory/Antioxidant Activities of Mediterranean Olive and Fig Leaves Extracts. Molecules 2020, 25, 1718. [CrossRef]

44. Schmidt, M.M.; Kubota, E.H.; Prestes, R.C.; Mello, R.O.; Rosa, C.S.; Scapin, G.; Ferreira, S. Development and evaluation of pork burger with added natural antioxidant based on extract of banana inflorescence (Musa cavendishii). CyTA J. Food 2016, 14, 280-288 [CrossRef]

45. Jin, S.K.; Ha, S.R.; Choi, J.S. Effect of Caesalpinia sappan L. extract on physico-chemical properties of emulsion-type pork sausage during cold storage. Meat Sci. 2015, 110, 245-252. [CrossRef] [PubMed]

46. Ali, F.; Abdel-Atty, N.; Helmy, E. Improving the quality and extending the shelf life of chilled fresh sausages using natural additives and their extracts. J. Microbiol. Biotechnol. Food Sci. 2018, 7, 580-585. [CrossRef]

47. Pateiro, M.; Franco, D.; Carril, J.A.; Lorenzo, J.M. Changes on physico-chemical properties, lipid oxidation and volatile compounds during the manufacture of celta dry-cured loin. J. Food Sci. Technol. 2015, 52, 4808-4818. [CrossRef]

48. Alirezalu, K.; Hesari, J.; Nemati, Z.; Munekata, P.E.S.; Barba, F.J.; Lorenzo, J.M. Combined effect of natural antioxidants and antimicrobial compounds during refrigerated storage of nitrite-free frankfurter-type sausage. Food Res. Int. 2019, 120, 839-850. [CrossRef] [PubMed]

49. Zamuz, S.; López-Pedrouso, M.; Barba, F.J.; Lorenzo, J.M.; Domínguez, H.; Franco, D. Application of hull, bur and leaf chestnut extracts on the shelf-life of beef patties stored under MAP: Evaluation of their impact on physicochemical properties, lipid oxidation, antioxidant, and antimicrobial potential. Food Res. Int. 2018, 112, 263-273. [CrossRef] [PubMed]

50. Amaral, A.B.; da Silva, M.V.; da Lannes, S.C.S. Lipid oxidation in meat: Mechanisms and protective factors-A review. Food Sci. Technol. 2018, 38, 1-15. [CrossRef]

51. Vargas-Sánchez, R.D.; Torrescano-Urrutia, G.R.; Torres-Martínez, B.D.M.; Pateiro, M.; Lorenzo, J.M.; Sánchez-Escalante, A. Propolis extract as antioxidant to improve oxidative stability of fresh patties during refrigerated storage. Foods $2019,8,614$. [CrossRef]

52. Zhang, Y.; Holman, B.W.B.; Ponnampalam, E.N.; Kerr, M.G.; Bailes, K.L.; Kilgannon, A.K.; Collins, D.; Hopkins, D.L. Understanding beef flavour and overall liking traits using two different methods for determination of thiobarbituric acid reactive substance (TBARS). Meat Sci. 2019, 149, 114-119. [CrossRef]

53. Georgantelis, D.; Blekas, G.; Katikou, P.; Ambrosiadis, I.; Fletouris, D.J. Effect of rosemary extract, chitosan and $\alpha$-tocopherol on lipid oxidation and colour stability during frozen storage of beef burgers. Meat Sci. 2007, 75, 256-264. [CrossRef] [PubMed]

54. Agrimonti, C.; White, J.C.; Tonetti, S.; Marmiroli, N. Antimicrobial activity of cellulosic pads amended with emulsions of essential oils of oregano, thyme and cinnamon against microorganisms in minced beef meat. Int. J. Food Microbiol. 2019, 305, 108246. [CrossRef]

55. Pateiro, M.; Munekata, P.E.S.; Sant'Ana, A.S.; Domínguez, R.; Rodríguez-Lázaro, D.; Lorenzo, J.M. Application of essential oils as antimicrobial agents against spoilage and pathogenic microorganisms in meat products. Int. J. Food Microbiol. 2021, 337,108966 [CrossRef] [PubMed]

56. Brodowska, A.J.; Nowak, A.; Śmigielski, K. Ozone in the food industry: Principles of ozone treatment, mechanisms of action, and applications: An overview. Crit. Rev. Food Sci. Nutr. 2018, 58, 2176-2201. [CrossRef] [PubMed]

57. Gómez, B.; Munekata, P.E.S.; Gavahian, M.; Barba, F.J.; Martí-Quijal, F.J.; Bolumar, T.; Campagnol, P.C.B.; Tomasevic, I.; Lorenzo, J.M. Application of pulsed electric fields in meat and fish processing industries: An overview. Food Res. Int. 2019, 123, 95-105. [CrossRef] [PubMed]

58. Domínguez, R.; Barba, F.J.; Gómez, B.; Putnik, P.; Bursać Kovačević, D.; Pateiro, M.; Santos, E.M.; Lorenzo, J.M. Active packaging films with natural antioxidants to be used in meat industry: A review. Food Res. Int. 2018, 113, 93-101. [CrossRef]

59. Gómez, I.; Janardhanan, R.; Ibañez, F.C.; Beriain, M.J. The Effects of Processing and Preservation Technologies on Meat Quality: Sensory and Nutritional Aspects. Foods 2020, 9, 1416. [CrossRef]

60. Duarte, A.; Luís, Â.; Oleastro, M.; Domingues, F.C. Antioxidant properties of coriander essential oil and linalool and their potential to control Campylobacter spp. Food Control 2016, 61, 115-122. [CrossRef]

61. Rocchetti, G.; Bernardo, L.; Pateiro, M.; Barba, F.J.; Munekata, P.E.S.; Trevisan, M.; Lorenzo, J.M.; Lucini, L. Impact of a Pitanga Leaf Extract to Prevent Lipid Oxidation Processes during Shelf Life of Packaged Pork Burgers: An Untargeted Metabolomic Approach. Foods 2020, 9, 1668. [CrossRef] [PubMed]

62. Falowo, A.B.; Muchenje, V.; Hugo, C.J.; Charimba, G. In vitro antimicrobial activities of Bidens pilosa and Moringa oleifera leaf extracts and their effects on ground beef quality during cold storage. CyTA J. Food 2016, 14, 541-546. [CrossRef] 
63. Angelini, P.; Matei, F.; Flores, G.A.; Pellegrino, R.M.; Vuguziga, L.; Venanzoni, R.; Tirillini, B.; Emiliani, C.; Orlando, G.; Menghini, L.; et al. Metabolomic Profiling, Antioxidant and Antimicrobial Activity of Bidens pilosa. Processes 2021, 9, 903. [CrossRef]

64. Martínez, L.; Bastida, P.; Castillo, J.; Ros, G.; Nieto, G. Green alternatives to synthetic antioxidants, antimicrobials, nitrates, and nitrites in clean label Spanish chorizo. Antioxidants 2019, 8, 184. [CrossRef]

65. Biswas, B.; Rogers, K.; McLaughlin, F.; Daniels, D.; Yadav, A. Antimicrobial activities of leaf extracts of guava (Psidium guajava L.) on two gram-negative and gram-positive bacteria. Int. J. Microbiol. 2013, 2013. [CrossRef] [PubMed]

66. Yang, X.; Boyle, R.A. Sensory Evaluation of Oils/Fats and Oil/Fat-Based Foods. In Oxidative Stability and Shelf Life of Foods Containing Oils and Fats; Hu, M., Jacobsen, C., Eds.; Elsevier: Amsterdam, The Netherlands, 2016; pp. $157-185$.

67. Shene, C.; Canquil, N.; Jorquera, M.; Pinelo, M.; Rubilar, M.; Acevedo, F.; Vergara, C.; von Baer, D.; Mardones, C. In vitro Activity on Human Gut Bacteria of Murta Leaf Extracts (Ugni molinae turcz.), a Native Plant from Southern Chile. J. Food Sci. 2012, 77, M323-M329. [CrossRef]

68. Arancibia-Radich, J.; Peña-Cerda, M.; Jara, D.; Valenzuela-Bustamante, P.; Goity, L.; Valenzuela-Barra, G.; Silva, X.; Garrido, G.; Delporte, C.; Seguel, I. Comparative study of anti-inflammatory activity and qualitative-quantitative composition of triterpenoids from ten genotypes of Ugni molinae. Bol. Latinoam. Caribe Plantas Med. Aromat. 2016, 15, 274-287.

69. Rubilar, M.; Jara, C.; Poo, Y.; Acevedo, F.; Gutierrez, C.; Sineiro, J.; Shene, C. Extracts of maqui (Aristotelia chilensis) and murta (Ugni molinae Turcz.): Sources of antioxidant compounds and $\alpha$-glucosidase/ $\alpha$-amylase inhibitors. J. Agric. Food Chem. 2011, 59, 1630-1637. [CrossRef]

70. Scheuermann, E.; Seguel, I.; Montenegro, A.; Bustos, R.O.; Hormazábal, E.; Quiroz, A. Evolution of aroma compounds of murtilla fruits (Ugni molinae Turcz) during storage. J. Sci. Food Agric. 2008, 88, 485-492. [CrossRef]

71. Peña-Cerda, M.; Arancibia-Radich, J.; Valenzuela-Bustamante, P.; Pérez-Arancibia, R.; Barriga, A.; Seguel, I.; García, L.; Delporte, C. Phenolic composition and antioxidant capacity of Ugni molinae Turcz. leaves of different genotypes. Food Chem. 2017, 215, 219-227. [CrossRef] [PubMed]

72. Hauser, C.; Peñaloza, A.; Guarda, A.; Galotto, M.J.; Bruna, J.E.; Rodríguez, F.J. Development of an Active Packaging Film Based on a Methylcellulose Coating Containing Murta (Ugni molinae Turcz) Leaf Extract. Food Bioprocess Technol. 2016, 9, $298-307$. [CrossRef]

73. Brito, A.; Areche, C.; Sepúlveda, B.; Kennelly, E.J.; Simirgiotis, M.J. Anthocyanin Characterization, Total Phenolic Quantification and Antioxidant Features of Some Chilean Edible Berry Extracts. Molecules 2014, 19, 936. [CrossRef]

74. Cespedes, C.L.; Balbontin, C.; Avila, J.G.; Dominguez, M.; Alarcon, J.; Paz, C.; Burgos, V.; Ortiz, L.; Peñaloza-Castro, I.; Seigler, D.S.; et al. Inhibition on cholinesterase and tyrosinase by alkaloids and phenolics from Aristotelia chilensis leaves. Food Chem. Toxicol. 2017, 109, 984-995. [CrossRef]

75. Jara-Moreno, D.; Castro-Torres, R.D.; Ettcheto, M.; Auladell, C.; Kogan, M.J.; Folch, J.; Verdaguer, E.; Cano, A.; Busquets, O.; Delporte, C.; et al. The Ethyl Acetate Extract of Leaves of Ugni molinae Turcz. Improves Neuropathological Hallmarks of Alzheimer's Disease in Female APPswe/PS1dE9 Mice Fed with a High Fat Diet. J. Alzheimer's Dis. 2018, 66, 1175-1191. [CrossRef]

76. Fuentes, L.; Figueroa, C.R.; Valdenegro, M.; Vinet, R. Patagonian Berries: Healthy Potential and the Path to Becoming Functional Foods. Foods 2019, 8, 289. [CrossRef] [PubMed]

77. Chacón-Fuentes, M.; Mutis, A.; Bardehle, L.; Seguel, I.; Urzúa, A.; Quiroz, A. Decrease of flavonol synthase enzymatic activity in Ugni molinae turcz due to the domestication process. Int. J. Agric. Nat. Resour. 2019, 46, 30-39. [CrossRef]

78. López, J.; Gálvez, A.V.; Rodríguez, A.; Uribe, E. Murta (Ugni molinae Turcz.): A review on chemical composition, functional components and biological activities of leaves and fruits. Chil. J. Agric. Anim. Sci. 2018, 34, 43-56. [CrossRef]

79. Rubilar, M.; Pinelo, M.; Ihl, M.; Scheuermann, E.; Sineiro, J.; Nuñez, M.J. Murta leaves (Ugni molinae Turcz) as a source of antioxidant polyphenols. J. Agric. Food Chem. 2006, 54, 59-64. [CrossRef]

80. Rubilar, M.; Gutiérrez, C.; Villarroel, M.; Shene, C. Influence of separation conditions on antimicrobial activity of polyphenolic fractions from murta leaves extract. CyTA J. Food 2010, 8, 139-149. [CrossRef]

81. Hauser, C.; Peñaloza, A.; Rodríguez, F.; Guarda, A.; Galotto, M.J. Promising antimicrobial and antioxidant extracts of Murta leaves (Ugni molinae Turcz): Shelf-life extension and food safety. Food Packag. Shelf Life 2014, 1, 77-85. [CrossRef]

82. Misle, E.; Garrido, E.; Contardo, H.; González, W. Maqui [Aristotelia chilensis (Mol.) Stuntz]-the Amazing Chilean Tree: A Review. J. Agric. Sci. Technol. B 2011, 1, 473-482.

83. Ipinza Carmona, R.; Magni Díaz, C.; Gutiérrez Caro, B.; Torres Cuadros, J. La domesticación del maqui (Aristotelia chilensis): Un estudio de caso en Chile. INFOR 2019, Diciembre, 19-24.

84. Muñoz, O.; Christen, P.; Cretton, S.; Backhouse, N.; Torres, V.; Correa, O.; Costa, E.; Miranda, H.; Delporte, C. Chemical study and anti-inflammatory, analgesic and antioxidant activities of the leaves of Aristotelia chilensis (Mol.) Stuntz, Elaeocarpaceae. J. Pharm. Pharmacol. 2011, 63, 849-859. [CrossRef] [PubMed]

85. Di Lorenzo, A.; Sobolev, A.P.; Nabavi, S.F.; Sureda, A.; Moghaddam, A.H.; Khanjani, S.; Di Giovanni, C.; Xiao, J.; Shirooie, S.; Tsetegho Sokeng, A.J.; et al. Antidepressive effects of a chemically characterized maqui berry extract (Aristotelia chilensis (molina) stuntz) in a mouse model of Post-stroke depression. Food Chem. Toxicol. 2019, 129, 434-443. [CrossRef] [PubMed]

86. Ojeda, J.; Evelyn, J.A.R.A.; Molina, L.; Parada, F.; Burgos, R.A.; Hidalgo, M.A.; Hancke, J.L. Effects of Aristotelia chilensis berry juice on cyclooxygenase 2 expression, NF-KB, NFAT, ERK1/2 and PI3K/Akt activation in colon cancer. Bol. Latinoam. Caribe Plantas Med. Aromat. 2011, 10, 543-552. 
87. Cifuentes, F.; Palacios, J.; Paredes, A.; Nwokocha, C.; Paz, C. 8-Oxo-9-Dihydromakomakine Isolated from Aristotelia chilensis Induces Vasodilation in Rat Aorta: Role of the Extracellular Calcium Influx. Molecules 2018, 23, 3050. [CrossRef] [PubMed]

88. Romero, F.; Palacios, J.; Jofré, I.; Paz, C.; Nwokocha, C.R.; Paredes, A.; Cifuentes, F. Aristoteline, an Indole-Alkaloid, Induces Relaxation by Activating Potassium Channels and Blocking Calcium Channels in Isolated Rat Aorta. Molecules 2019, 24, 2748. [CrossRef] [PubMed]

89. Rojo, L.E.; Ribnicky, D.; Logendra, S.; Poulev, A.; Rojas-Silva, P.; Kuhn, P.; Dorn, R.; Grace, M.H.; Lila, M.A.; Raskin, I. In vitro and in vivo anti-diabetic effects of anthocyanins from Maqui Berry (Aristotelia chilensis). Food Chem. 2012, 131, 387-396. [CrossRef] [PubMed]

90. Alvarado, J.; Schoenlau, F.; Leschot, A.; Salgad, A.M.; Portales, P.V. Delphinol ${ }^{\circledR}$ standardized maqui berry extract significantly lowers blood glucose and improves blood lipid profile in prediabetic individuals in three-month clinical. Panminerva Med. 2016, 58, 1-6.

91. Zúñiga, G.E.; Tapia, A.; Arenas, A.; Contreras, R.A.; Zúñiga-Libano, G. Phytochemistry and biological properties of Aristotelia chilensis a Chilean blackberry: A review. Phytochem. Rev. 2017, 16, 1081-1094. [CrossRef]

92. Schön, C.; Wacker, R.; Micka, A.; Steudle, J.; Lang, S.; Bonnländer, B. Bioavailability Study of Maqui Berry Extract in Healthy Subjects. Nutrients 2018, 10, 1720. [CrossRef] [PubMed]

93. Resolución 548 Exenta. In Listado de Medicamentos Herbarios Tradicionales. Available online: https://www.minsal.cl/mht/ (accessed on 3 July 2021).

94. Cespedes, C.L.; Pavon, N.; Dominguez, M.; Alarcon, J.; Balbontin, C.; Kubo, I.; El-Hafidi, M.; Avila, J.G. The chilean superfruit black-berry Aristotelia chilensis (Elaeocarpaceae), Maqui as mediator in inflammation-associated disorders. Food Chem. Toxicol. 2017, 108, 438-450. [CrossRef] [PubMed]

95. Rodríguez, K.; Ah-Hen, K.S.; Vega-Gálvez, A.; Vásquez, V.; Quispe-Fuentes, I.; Rojas, P.; Lemus-Mondaca, R. Changes in bioactive components and antioxidant capacity of maqui, Aristotelia chilensis [Mol] Stuntz, berries during drying. LWT Food Sci. Technol. 2016, 65, 537-542. [CrossRef]

96. Schreckinger, M.E.; Lotton, J.; Lila, M.A.; de Mejia, E.G. Berries from South America: A comprehensive review on chemistry, health potential, and commercialization. J. Med. Food 2010, 13, 233-246. [CrossRef] [PubMed]

97. Vidal, J.L.; Avello, L.M.; Loyola, C.C.; Campos, P.J.; Aqueveque, M.P.; Dungan, R.S.; Galotto, L.M.; Guarda, M.A. Microencapsulation of maqui (Aristotelia chilensis [Molina] Stuntz) leaf extracts to preserve and control antioxidant properties. Chil. J. Agric. Res. 2013, 73, 17-23. [CrossRef]

98. Fredes, C.; Yousef, G.G.; Robert, P.; Grace, M.H.; Lila, M.A.; Gómez, M.; Gebauer, M.; Montenegro, G. Anthocyanin profiling of wild maqui berries (Aristotelia chilensis [Mol.] Stuntz) from different geographical regions in Chile. J. Sci. Food Agric. 2014, 94, 2639-2648. [CrossRef]

99. González-Villagra, J.; Cohen, J.D.; Reyes-Díaz, M.M. Abscisic acid is involved in phenolic compounds biosynthesis, mainly anthocyanins, in leaves of Aristotelia chilensis plants (Mol.) subjected to drought stress. Physiol. Plant. 2019, 165, 855-866. [CrossRef] [PubMed]

100. Berardo, A.; Claeys, E.; Vossen, E.; Leroy, F.; De Smet, S. Protein oxidation affects proteolysis in a meat model system. Meat Sci. 2015, 106, 78-84. [CrossRef]

101. Pateiro, M.; Domínguez, R.; Munekata, P.E.S.; Barba, F.J.; Lorenzo, J.M. Lipids and fatty acids. In Innovative Thermal and NonThermal Processing, Bioaccessibility and Bioavailability of Nutrients and Bioactive Compounds; Barba, F., Saraiva, J.A., Cravotto, G., Lorenzo, J.M., Eds.; Elsevier: Amsterdam, The Netherlands, 2019; pp. 107-137. ISBN 9780128141748.

102. Avello, M.; Valdivia, R.; Sanzana, R.; Mondaca, M.A.; Mennickent, S.; Aeschlimann, V.; Bittner, M.; Becerra, J. Extractos antioxidantes y antimicrobianos de Aristotelia chilensis y Ugni molinae y sus aplicaciones como preservantes en productos cosméticos. Bol. Latinoam. Caribe Plantas Med. Aromat. 2009, 8, 479-486. 